Fournal of Medical Genetics (1973). 10, 142.

\title{
Origin of 48,XXXY: The Evidence of the Xg Blood Groups
}

\section{R. A. PFEIFFER* and RUTH SANGER $\dagger$}

\begin{abstract}
Summary. A third family is reported in which the $\mathrm{Xg}$ groups give information about the origin of an XXXY member: successive non-disjunction at the first and second paternal meiotic divisions is much the most likely cause. In the two previous informative families successive non-disjunction at maternal meiotic divisions was the most likely cause. An enquiry showed the average age of 29 fathers at the birth of XXXY sons to be 32.41 years.
\end{abstract}

The gonosomal complement XXXY appears to be less frequent than other polysomies. Some 30 cases have been published. During 10 years the MRC Blood Group Unit was sent blood samples for $\mathrm{Xg}$ grouping from only 15 propositi compared with 471 samples from XXY and 38 from XXXXY propositi. Samples were available from both parents of six of the $15 \mathrm{XXXY}$ propositi, but only one family was informative: the propositus was $\mathrm{Xg}(\mathrm{a}-)$, his father $\mathrm{Xg}(\mathrm{a}+)$, and his mother $\mathrm{Xg}(\mathrm{a}-)$, thus showing that all three of the patient's Xs were maternal, and non-disjunction at both the first and second maternal meiotic divisions was assumed to be the most likely cause of the aneuploidy (see the case of H. Zollinger and G. Mürset, cited in Sanger, Tippett, and Gavin, 1971, p. 418). A similar case was reported by Greenstein et al (1970).

The Xg groups of the family of a further XXXY propositus have now been studied and are informative: father $\mathrm{Xg}(\mathrm{a}-)$, mother $\mathrm{Xg}(\mathrm{a}+), \mathrm{XXXY}$ propositus $\mathrm{Xg}(\mathrm{a}-)$, two sisters $\mathrm{Xg}(\mathrm{a}-)$, and one sister $\mathrm{Xg}(\mathrm{a}+)$. The mother must be heterozygous, $X g^{a} X g$, because two of her daughters are $\mathrm{Xg}(\mathrm{a}-)$. Hence, non-disjunction at the first maternal meiotic division can be ruled out.

Alternate paths are: (1) coincidental non-disjunction in the formation of both gametes, at the first paternal and the second maternal meiotic divisions; (2) successive postzygotic non-disjunctions with the elimination of all cell lines other than XXXY; (3) a combination of meiotic and postzygotic errors,

\footnotetext{
Received 21 November 1971.

* Institut für Humangenetik der Universität Münster, Federal Republic of Germany.

† MRC Blood Group Unit, Lister Institute, London SW1W 8RH.
}

again with elimination of all cell lines other than XXXY. Since no cells other than lymphocytes were studied tissue mosaicism cannot be excluded formally, but seems unlikely; (4) successive nondisjunction at the first and second divisions at paternal meiosis.

The last pathway seems much the most plausible, just as successive non-disjunction at the first and second divisions of maternal meiosis best interprets the Xg groups of the XXXY propositi of Greenstein et al (1970) and of H. Zollinger and G. Mürset. Successive non-disjunction at paternal meiosis also explained the only two XXYY families in which the $\mathrm{Xg}$ groups have been informative (de la Chapelle et al, 1964; Pfeiffer et al, 1966).

Both parents of our propositus were aged 46 at his birth.

Successive paternal non-disjunction might be expected to reflect a raised average age of fathers at the birth of an XXXY son, and successive maternal non-disjunction a raised average age of mothers and indirectly of fathers; the same increased average age might be expected of the fathers of XXYY sons. The mean age of fathers of children in a very large Australian series was 31.04 years and that in a smaller series in Great Britain 31.69 years (see Blank, 1960). These figures do not differ essentially from the mean age of 29 fathers of XXXY sons, which we found on enquiry to be $32 \cdot 41, \mathrm{SE}=$ 1.42. Nor do they differ from the mean age of 33 fathers of XXYY sons which was 33.39, SE $=1.69$ (Borgaonkar, Mules, and Char, 1970).

If there is an association between paternal age and $\mathrm{XXXY}$ and XXYY the present data are too few to show it. 
For information about the paternal age of XXXY sons we thank Drs A. Frøland, R. Hunter, H. van den Berghe, P. E. Polani, O. Dubois, and J. Aitken.

\section{REFERENCES}

Blank, C. E. (1960). Apert's syndrome (a type of acrocephalosyndactyly)-observations on a British series of thirty-nine cases. Annals of Human Genetics, 24, 151-164.

Borgaonkar, D. S., Mules, E., and Char, F. (1970). Do the 48,XXYY males have a characteristic phenotype? A review. Clinical Genetics, 1, 272-293.
Chapelle, A. de la, Hortling, H., Sanger, R., and Race, R. R. (1964). Successive non-disjunction at first and second meiotic division of spermatogenesis: evidence of chromosomes and $\mathrm{Xg}$. Cytogenetics, 3, 334-341.

Greenstein, R. M., Harris, D. J., Luzzatti, L., and Cann, H. M. (1970). Cytogenetic analysis of a boy with the XXXY syndrome; origin of the X-chromosomes. Pediatrics, 45, 677-686.

Pfeiffer, R. A., Körver, G., Sanger, R., and Race, R. R. (1966) Paternal origin of an XXYY anomaly. Lancet, 1, 1427-1428.

Sanger, R., Tippett, P., and Gavin, J. (1971). Xg groups and sex abnormalities in people of Northern European ancestry. Fournal of Medical Genetics, 8, 417-426. 